\title{
SISTEM INFORMASI GEOGRAFIS PENDATAAN BANGUNAN BERDASARKAN IZIN MENDIRIKAN BANGUNAN DI KABUPATEN MERAUKE
}

\author{
Agustan Latif ${ }^{1}$ dan Suwarjono ${ }^{2}$ \\ (1) Jurusan Sistem Informasi, Fakultas Teknik, Universitas Musamus Merauke (0971) 325747 \\ (2) Jurusan Teknik Informatika, Fakultas Teknik, Universitas Musamus Merauke (0971) 325747 \\ 1agustan@unmus.ac.id, 2jono.musamus@gmail.com
}

\begin{abstract}
Abstrak
Sistem Informasi Geografis pendataan bangunan merupakan kebutuhan administrasi pada Dinas Tata Kota dan Pemakaman Kabupaten Merauke yang dapat membantu pendataan dan analisis kepadatan bangunan. Sistem mempermudah pengguna dalam menganalisis kepadatan bangunan. Tujuan penelitian ini untuk membangun sebuah sistem informasi geografis pendataan bangunan berdasarkan izin mendirikan bangunan di Kabupaten Merauke.

Model yang digunakan untuk membangun sistem menerapkan metode waterfall melalui beberapa tahap yaitu wawancara, observasi, riset kepustakaan pada objek penelitian. Tahap perancangan menggambarkan alur data sistem, bahasa pemprograman yang digunakan C\# dengan Microsoft Acces 2010 sebagai database engine dan Google Map untuk menampilkan peta. Tahap pengujian sistem menggunakan metode black box dan kuisioner.

Sistem Informasi Geografis Pendataan Bangunan Berdasarkan Ijin Mendirikan Bangunan dapat membantu proses pemetaan wilayah dan bangunan yang telah memiliki IMB dan dapat menganalisis kepadatan bangunan pada Kabupaten Merauke yang berdasarkan pada banyak rumah dan luas tanah yang terpakai ditentukan berdasarkan Keputusan Menteri PU No. 378/KPTS/1987.
\end{abstract}

Kata Kunci :Sistem Informasi Geografis (SIG), Izin Mendirikan Bangunan (IMB), Database

\section{Pendahuluan}

Dinas Tata Kota dan Pemakaman merupakan institusi pemerintahan Kota Merauke yang beralamat di Jalan Trikora. Dinas ini terbagi menjadi empat bidang yaitu Bidang Program Perkotaan, Bidang Perizinan Bangunan, Bidang Perumahan dan Pemukiman, dan Bidang Prasarana Bangunan Gedung. Dinas Tata Kota dan Pemakaman mempunyai tugas pokok melaksanakan urusan pemerintah daerah berdasarkan asas otonomi dan tugas pembantuan di bidang-bidang yang ada.

Proses pendataan bangunan yang dilakukan secara manual sangat memungkinkan terjadi kesalahan pada saat rekapitulasi bangunan-bangunan yang telah memiliki Izin Mendirikan Bangunan. Kondisi ini memerlukan ketelitian dalam proses pendataan dan rekapituasi sehingga dalam penyajian laporan pendataan dan proses analisa kepadatana bangunan memerlukan waktu yang cukup lama. Izin Mendirikan Bangunan merupakan izin yang diberikan kepada orang pribadi atau badan untuk mendirikan bangunan sesuai dengan tata ruang yang berlaku dengan syarat-syarat keselamatan bagi yang akan menempati bangunan tersebut. Izin ini diberikan untuk melakukan pengendalian dan pengawasan atas bangunan yang didirikan.

Pergerakkan pembangunan yang mengalami pertumbuhan sangat cepat dan melihat dari perkembangan data spasial dalam dekade balakangan ini meningkat dengan sangat drastis. Era komputerisasi telah membuka wawasan dan paradigma baru dalam proses pengambilan keputusan dan penyebaran informasi. Hal ini berkaitan dengan meluasnya pemanfaatan Sistem Informasi Geografis (SIG) dan perkembangan teknologi dalam memperoleh, merekam, dan mengumpulkan data yang bersifat keruangan (spasial).

Permasalahan yang kemudian mucul yakni bagaimana melakukan pendataan bangunan berdasarkan Izin Mendirikan Bangunan dan bagaimana menginformasikan dan menganalisis kepadatan dan bangunan pada suatu wilayah.

Dengan perkembangan informasi yang semakin cepat diharapkan pemerintah daerah dapat mengambil langkah-langkah antisipatif dalam rangka pengendalian dan pembangunan yang berkelanjutan. Sistem yang dibangun ini bertujuan membantu proses pendataan bangunan yang telah memiliki Izin Mendirikan Bangunan pasa setiap kelurahan sehingga dapat menganalisis kepadatan bangunan dari setiap kelurahan di Kabupaten Merauke

Beberapa penelitian yang relevan dengan penelitian terhadap pemanfaatan sistem informasi geografis yakni penelitian sehubungan dengan sistem informasi geografis untuk mengetahui penyebaran penduduk di Kabupaten Sleman berdasarkan tingkat usianya. Diharapkan dengan adanya sistem ini dapat mempermudah instansi terkait untuk mengetahui potensi penduduk (usia produktif dan non-produktif) dari suatu daerah [1]. Sistem informasi geografis SIG dapat menampilkan informasi yang beragam dalam suatu bidang gambar. Salah satu sistem informasi yang dapat dikembangkan untuk memberikan informasi hasil suara pemilihan umum kepala daerah di Kabupaten Jombang adalah dengan menggunakan Sistem Informasi Geografis (SIG) berbasis open source. Sistem yang dihasilkan memiliki fitur menampilkan data Daftar Pemilih Tetap, persentase perolehan suara, persentase golput, jumlah penduduk berdasarkan kelompok umur dan jenis kelamin, mata pencaharian penduduk yang 263 
disajikan dalam bentuk grafis (peta). Teknologi SIG berbasis web dalam sistem ini dapat menjadi media informasi yang dapat membantu pihak yang berkepentingan dalam pengambilan keputusan, terutama pihak yang berkaitan dalam proses politik [2].

Sistem Informasi Geografis (SIG) atau Geohraphic Information System (GIS) adalah sebuah sistem yang didesain untuk menangkap, menyimpan, memanipulasi, menganalisa, mengatur, dan menampilkan seluruh jenis data geografi [3].

Sistem informasi Geografis (SIG) saat ini merupakan perangkat bantu dalam pemetaan serta manajemen informasi berbasis geografis. Melalui perangkat ini kita dapat memvisualisasikan keadaan nyata bumi (real world) menjadi suatu gambar, Perangkat ini juga membantu kita memahami konsepkonsep fenomena alam terkait aspek geografis maupun keruangan sehingga memudahkan kita mengambil keputusan-keputusan perencanaan maupun pengelolaan sesuai dengan kebutuhan [4].

Intensitas ruang dalah besaran ruang untuk fungsi tertentu yang ditentukan berdasakan pengaturan koefisiensi lantai bangunan, koefisiensi dasar bangunan, koefisiensi dasar hijau, kepadatan penduduk, dan/atau kepadatan bangun tiap persil, tapak, blok peruntukan, atau kawasan kota sesuai dengan kedudukan dan fungsinya dalam pembangunan kota. Maka intensitas ruang pada kota Merauke dapat dilihat secara tata bangunan dan lingkungan.

Kepadatan bangunan adalah banyaknya intensitas bangunan pada sebuah kawasan. Kepadatan ini diperlukan untuk membedakan kapasitas jumlah bangunan pada suatu kawasan. Adapun klasifikasi intensitas atau kepadatan bangunan didasarkan pada standar klasifikasi kepadatan bangunan berdasarkan Kepmen PU No. 378/KPTS/1987 yang dapat dilihat pad tabel berikut:[5].

Tabel 1. Klasifikasi Kepadatan Bangunan

\begin{tabular}{|l|c|}
\hline \multicolumn{1}{|c|}{ Klasifikasi } & Kepadatan Bangunan \\
\hline Sangat Rendah & $\leq 10$ bangunan/ha \\
\hline Rendah & $11-40$ bangunan/ha \\
\hline Sedang & $41-60$ bangunan/ha \\
\hline Tinggi & $61-80$ bangunan/ha \\
\hline Sangat Tinggi & $\geq 81$ bangunan/ha \\
\hline \multicolumn{2}{|c|}{ Sumber: Keputusan Menteri pu No. $378 /$ KPTS/1987, }
\end{tabular}

\section{Metodologi}

Metodologi yang digunakan dalam penelitian ini yaitu metodologi pengembangan sistem Waterfall. Pengembangan sistem dengan model air terjun (waterfall model) terdiri dari enam tahap yaitu : Rekayasa sistem (System Engineering), analisis, perancangan (design), penulisan program (coding), pengujian (testing), pemeliharaan (maintenance).

Tahap perancangan sistem merupakan tahap penggambaran atau identifikasi komponen-komponen fungsional yang digunakan dalam perencanaan pengembangan sistem. Tahap perancangan sistem ini bertujuan untuk mendesain sistem yang lengkap dan jelas yang akan digunakan dalam implementasi yang ditujukan untuk memenuhi kebutuhan pemakai sistem.

Pada proses perancangan awal dapat dijelaskan dengan menggunakan diagram konteks (Context Diagram) yaitu menggambarkan secara umum entitas luar yang terlibat, input yang dibutuhkan dan output yang dihasilkan oleh sistem yang akan dibangun. Entitas luar yang ada dalam sistem ini adalah Admin Pegawai dan Kepala Dinas. Untuk lebih jelasnya dapat dilihat pada Gambar 1 diagram konteks.

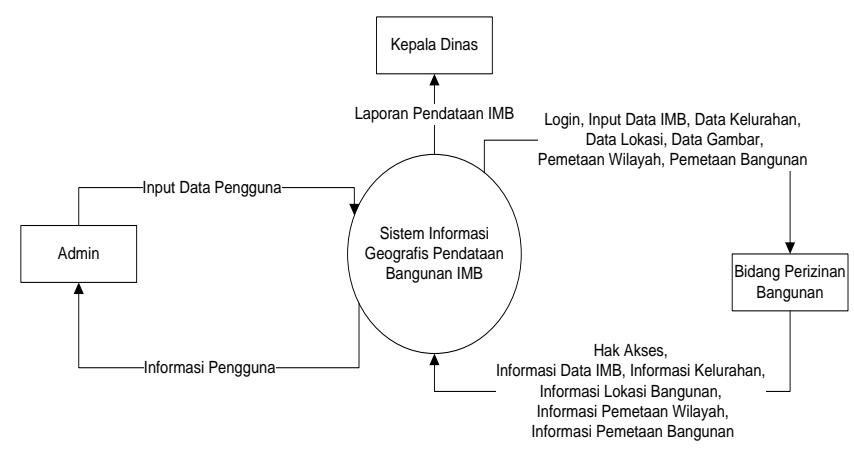

Gambar 1. Diagram Konteks

Berdasarkan Gambar 1 sistem memilki tiga entitas yaitu Admin, Kepala Dinas dan bidang perizinan bangunan. Admin bertugas mengelola pengguna sedangkan pegawai perizinan akan menginput data IMB, data kelurahan, data lokasi bangunan, data gambar, dan peta yang akan diolah oleh sistem yang akan menghasilkan informasi data IMB, informasi data kelurahan, informasi lokasi bangunan, dan informasi pemetaan bangunan. Kepala Dinas menerima laporan pendataan bangunan berdasarkan IMB

Data Flow Diagram (DFD) adalah salah satu model alat bantu atau modelingtools yang penting dan digunakan untuk menggambarakan aliran data dalam sistem baru, sumber dan tujuan data, proses yang mengolah data tersebut dan juga menyimpan data.

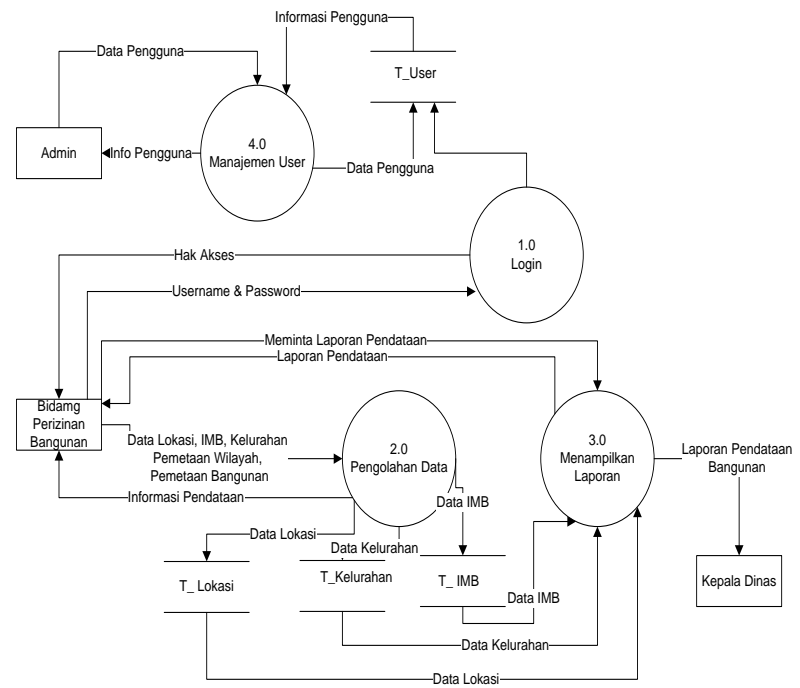

Gambar 2. DFD Level 0 Sistem Informasi Geografis Pendataan Banguanan Berdasarkan IMB 
.Pada Gambar 2 DFD Level 0 (diagram konteks). menunjukkan rancangan proses pada suatu proses dasar dari sistem. Proses dari seluruh sistem secara garis besar ditunjukan pada DFD Level 0 . Gambar 2 menggambarkan proses-proses yang ada pada sistem yang dimulai dengan proses Login, proses Pengolahan Data, proses Menampilkan laporan dan proses manajemen users, entitas yang ada pada sistem ini yaitu Admin, Bidang Perizinan Bangunan dan Kepala Dinas

Dari DFD Level 0 tersebut dapat dijabarkan ke dalam DFD Level 1 (seperti terlihat pada Gambar 3). DFD level 1 digunakan untuk memperjelas prosesproses yang terjadi di dalam sistem, proses dikelompokkan menjadi dua yaitu : Proses pengolahan data dan Proses laporan.

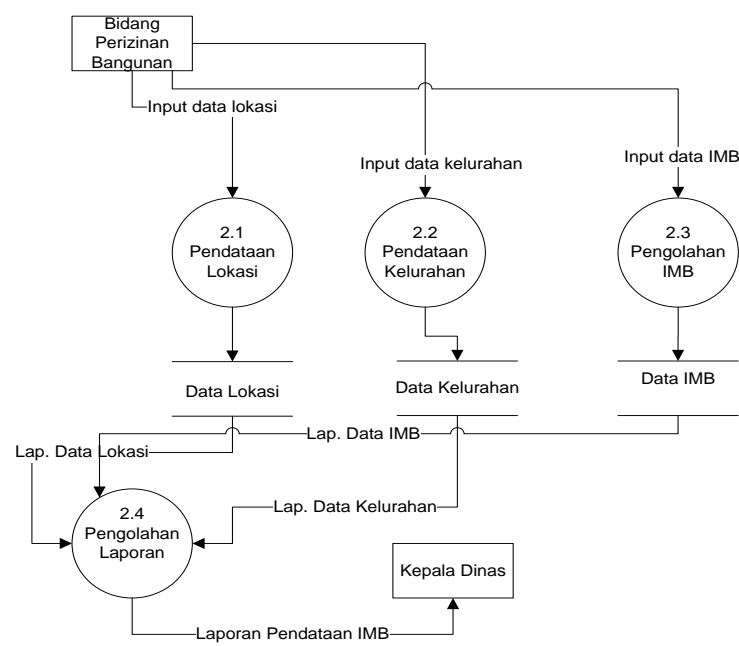

Gambar 3. DFD Level 1 Proses 2 Pengolahan Data

Gambar 3 menggambarkan proses-proses pengolahan data yang memproses Pendataan Lokasi, proses Pendataan Kelurahan dan proses Pengolahan IMB.

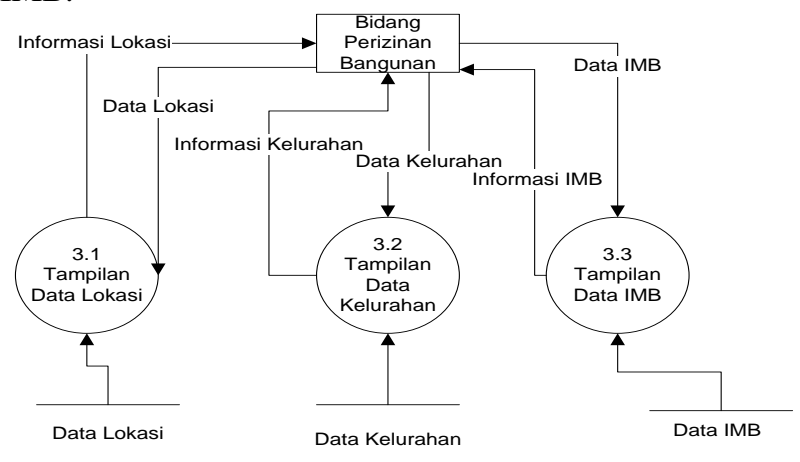

Gambar 4. DFD Level 1 Proses 3 Menampilkan Informasi

Gambar 4 menggambarkan proses-proses untuk menampilkan informasi yaitu proses Tampilkan Data Lokasi, proses Tampilan Data Kelurahan dan proses Tampilan Data IMB.

\section{Pembahasan}

\subsection{Implementasi Rancangan}

Pada bagian ini akan dijelaskan mengenai hasil implementasi sistem dan beberapa tampilan antara muka pengguna berdasarkan rancangan sistem.

\subsection{Tampilan Utama}

1. Tampilan Menu Utama

Tampilan Home merupakan tampilan yang akan muncul setelah pengguna melakukan proses Login. Tampilan ini menampilakan menu start, pengaturan, tampilan statistic peta, tools untuk melakukan pemetaan wilayah dan bangunan, pencarian wilayah dan pencarian rumah dapat dilihat pada Gambar 5.

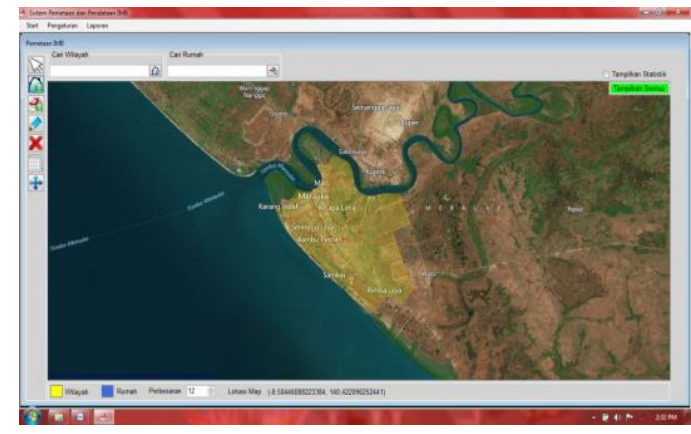

Gambar 5. Tampilan Menu Utama

\section{Tampilan Halaman Pemetaan IMB}

Pemetaan IMB ini memanfaatkan Google Map untuk menampilkan peta. Peta yang digunakan dalam pemetaan ini peta Kabupaten Merauke. Untuk dapat menampilkan peta sistem harus terkoneksi dengan internet agar dapat melakukan pemetaan peta. Pemetaan dimulai dengan menentukan objek-objek wilayah dengan bantuan tools. Tools yang digunakan bisa lihat pada Gambar 6

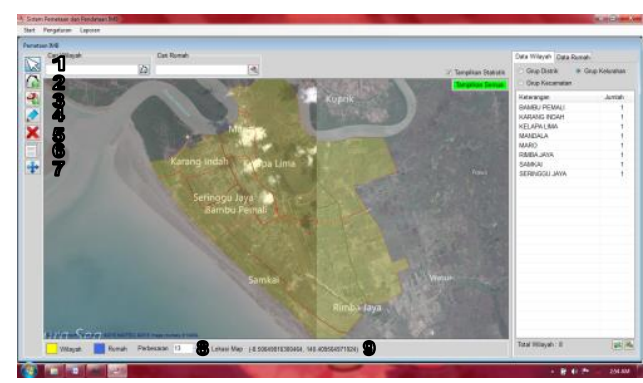

Gambar 6. Tools Pemetaan

Gambar 6 menunjukkan tools yang digunakan untuk melakukan pemetaan wilyah dan pemetaan bangunan. Untuk lebih jelasnya setiap tools dijabarkan sebagai berikut:

a. Tools 1, pada Gambar 6 digunakan untuk memilih objek yang akan dilakukan pemetaan.

b. Tools 2, pada Gambar 6 digunakan untuk pemetaan wilayah, seperti kelurahan. 


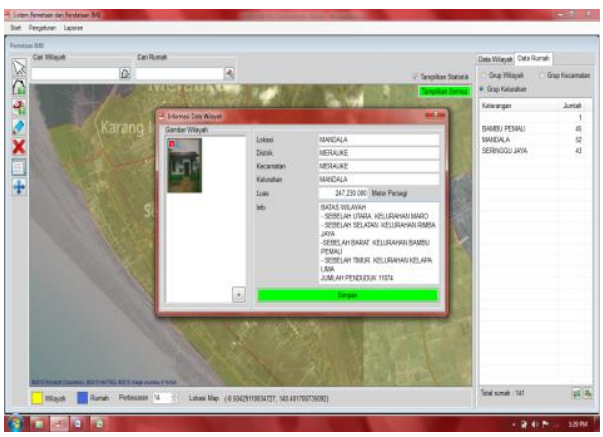

Gambar 7. Tampilan Pemetaan Wilayah

Gambar 7 merupakan tampilan pemetaan wilayah dengan menentukan titik-titik wilayah yang akan dipetakan, setelah melakukan pemetaan akan muncul form informasi data wilayah yang di gunakan untuk mengisi informasi wilayah seperti lokasi, kabupaten, kecamatan, kelurahan, luas, info dan gambar wilayah.

c. Tools 3 pada Gambar 6 digunakan untuk pemetaan menambah bangunan yang sudah memiliki IMB dapat dilihat pada Gambar 8.

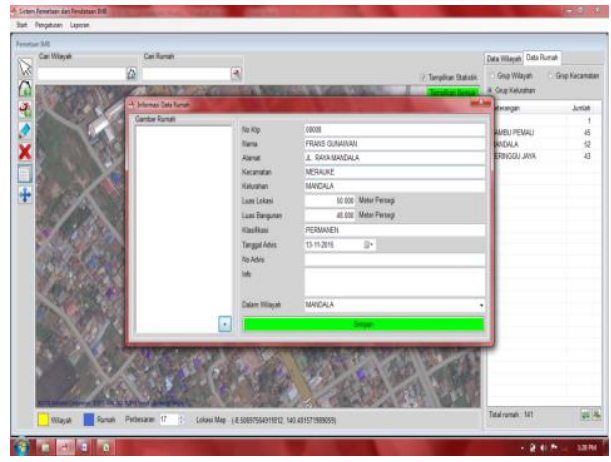

Gambar 8. Tampilan Pemetaan Bangunan

Gambar 8 merupakan tampilan pemetaan bangunan dengan menentukkan titik-titik lokasi bangunan yang sesuai dengan wilayah dan kelurahan dari bangunan tersebut. Setelah melakukan pemetaan bangunan makan akan muncul informasi data rumah yang harus diisi no.ktp pemilik, nama pemilik IMB, alamat, kecamatan, kelurahan, luas lokasi bangunan, luas bangunan, klasifikasi bangunan, tanggal advis, no advis, informasi, gambar rumah.

d. Tools 4, pada Gambar 6 digunakan untuk mengedit pemetaan wilayah Gambar 9.

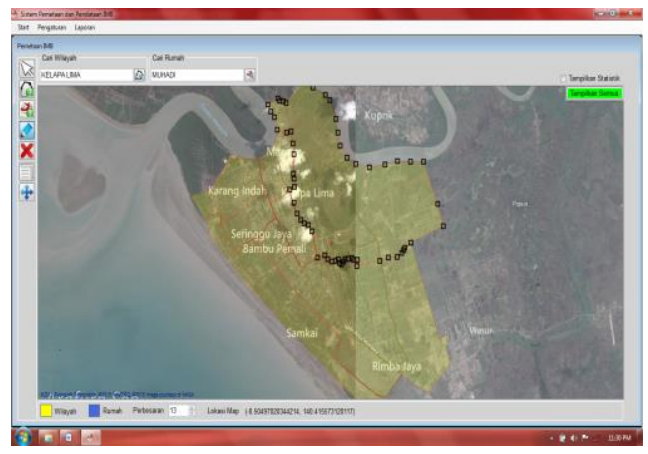

Gambar 9. Tampilan Edit Pemetaan Wilayah

Gambar 9 merupakan tampilan proses pengeditan pemetaan wilayah, proses pengeditan dimulai dengan memilih wilayah yang akan diedit. Pengeditan disesuiakan dengan peta.

e. Tools 5, pada Gambar 6 digunakan untuk menghapus pemetaan wilayah dan pemetaan bangunan.

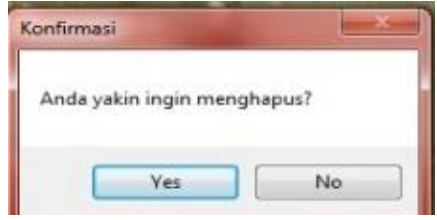

Gambar 10. Tampilan Konfirmasi Hapus Pemetaan

Gambar 10 merupakan tampilan konfirmasi hapus pemetaan, untuk menghapus wilayah atau menghapus bangunan dengan memilih wilyah atau bangunan yang akan dihapus.

f. Tools 6, pada Gambar 6 digunakan untuk mengedit informasi dari pemetaan wilayah dan pemetaan bangunan. Untuk mengedit informasi dimulai dengan memilih wilyah atau bangunan yang akan di edit.

g. Tools 7, pada Gambar 6 digunakan untuk memindahkan objek pemetaan.

h. Tools 8, pada Gambar 6 digunakan untuk memperbesar dan memperkecil peta pemetaan.

\section{Tampilan Menu Laporan}

Pada Menu Laporan terdapat sub menu wilayah dan sub menu rumah yang akan menampilkan laporan wilyah dan laporan rumah.

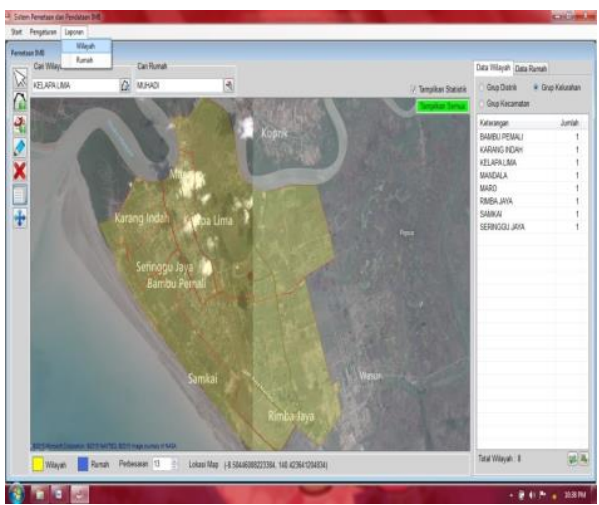

Gambar 11. Form Menu Laporan

Gambar 11 merupakan tampilan menu laporan yang berisi laporan wilayah dan laporan bangunan.

Pada sub menu laporan wilayah akan menampilkan laporan wilayah dari hasil pemetaan yang telah dilakukan. Pada laporan wilayah akan menampilkan nama, distrik, kecamatan, kelurahan, luas, total rumah, luas tanah rumah dan luas tanah bangunan. Pada bagian sudut kiri bawah menampilkan kesimpulan 
dari total wilayah hasil pemetaan, luas wilayah objek penelitian, total rumah yang memiliki IMB, luas tanah rumah, luas bangunan rumah yang telah digunakan, dan luas wilyah yang belum terpakai untuk dibangun dapat dilihat pada Gambar 12.

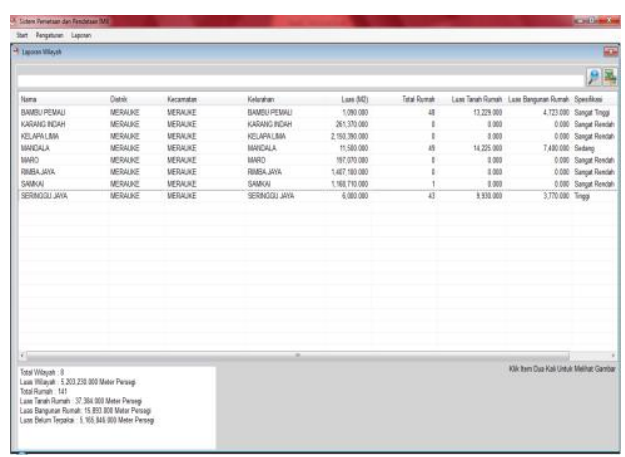

Gambar 12. Tampilan Laporan Wilayah

Gambar 12 merupakan tampilan laporan wilayah yang berisi nama kelurahan, distrik, kecamatan, kelurahan, luas kelurahan, total rumah, luas tanah rumah, luas bangunan rumah, dan pada bagian kiri bawah muncul informasi. Dari hasil pendataan dan pemetaan tersebut dengan memasukkan sampel pada penelitian ini yakni 3 kelurahan yaitu Kelurahan Bambu Pemali, Kelurahan Seringgu Jaya dan Kelurahan Mandala Distrik Merauke. Sehingga sistem dapat membantu menganalisa kepadatan bangunan dari masing-masing kelurahan. Dari hasil analisa kepadatan bangunan berdasarkan sampel bangunan yang diinputkan Kelurahan Bambu Pemali, Kelurahan Seringgu Jaya, dan Kelurahan Mandala masuk ke dalam spesifikasi kepadatan bangunan sangat rendah.

Pada sub menu Laporan Rumah akan menampilkan laporan rumah dari hasil pemetaan. Pada Laporan Rumah akan menampilan nama dari pemilik IMB, alamat pemilik IMB, kecamatan, kelurahan, luas tanah, luas bangunan. Pada bangian sudut kiri bawah menampilkan kesimpulan total rumah yang meiliki IMB, luas tanah rumah, luas bangunan rumah dan luas tanah yang belum terpakai dapat dilihat pada Gambar 13.

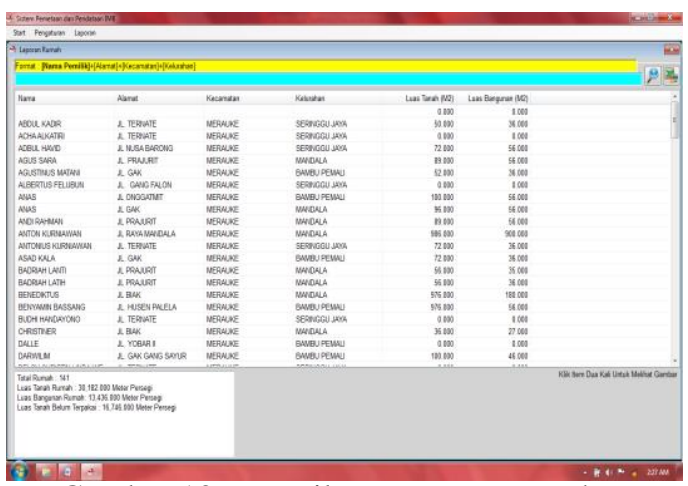

Gambar 13. Tampilan Laporan Rumah

Gambar 13 merupakan tampilan laporan ruamh yang berisi nama, alamat, kecamatan, kelurahan, luas tanah, luas bangunan, dan pada bagian kiri bawah menampilkan informasi keterangan dari laporan yaitu total rumah, luas luas tanah rumah, luas bangunan rumah, dan luas tanah yang belum terpakai.

Berdasarkan laporan yang dihasilkan Sistem Informasi Geografis Pendataan Bangunan Berdasarkan Izin Mendirikan Bangunan di Kabupaten Merauke dapat menunjukkan total bangunan yang telah memiliki IMB, luas tanah rumah, luas tanah rumah yang sudah terpakai dan luas tanah rumah yang belum terpakai sehingga dapat membantu pemerintah dalam menganalisis kepadatan bangunan di Kabupaten Merauke.

Penelitian ini memasukkan sampel 141 bangunan yang telah memiliki Izin Mendirikan Bangunan dari 3 kelurahan. Dari sampel tersebut dapat dilihat luas lahan yang sudah terpakai dan belum terpakai . hasil inputan sampel data dapat dilihat pada Gambar 14.

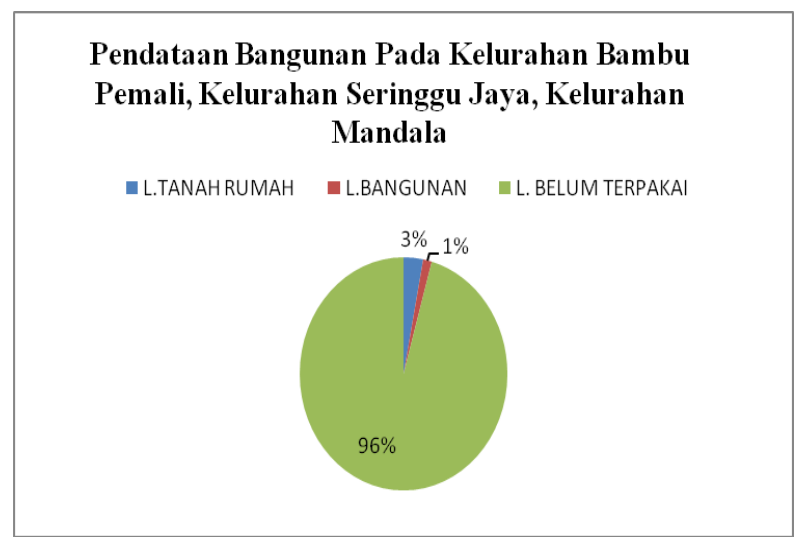

Gambar 14. Grafik Hasil Pendataan Bangunan Berdasarkan Gambar 14 hasil pendataan bangunan pada Kelurahan Bambu Pemali, Kelurahan Seringgu Jaya dan Kelurahan Mandala, dengan menggunakan sampel 141 rumah, luas tanah rumah 4\%, luas rumah $1 \%$ dan luas tanah yang belum terpakai 96\%. Dari hasil analisis kepadatan bangunan dapat membantu pemerintah dalam melakukan pengendalian arah pengembangan kota selanjutnya untuk menghindari resiko-resiko yang muncul dari pembangunan yang tidak sesuai dengan peruntukkan ruang, sehingga dapat terwujud suatu ruang yang selaras, seimbang dan harmonis.

\section{Kesimpulan}

Setelah melakukan analisis dan perancangan serta pembuatan Sistem Informasi Geografis Pendataan Bangunan Berdasarkan Izin Mendirikan Bangunan di Kabupaten Merauke", maka dapat ditarik kesimpulan sebagai berikut:

1. Penelitian ini menghasilkan sebuah sistem informasi geografis pendataan bangunan yang dapat membantu proses pemetaan wilayah dan pemetaan bangunan yang telah memiliki IMB.

2. Sistem Informasi Geografis Pendataan Bangunan Berdasarkan Izin Mendirikan Bangunan dapat menganalisis kepadatan bangunan pada Kabupaten Merauke yang berdasarkan banyak rumah setiap luasannya. Kepadatan bangunan ditentukan 
berdasarkan klasifikasi kepadatan bangunan berdasarkan Keputusan Menteri PU No. 378/KPTS/1987, lampiran No. 22. Selain itu sistem dapat menunjukkan total bangunan yang telah memiliki IMB, dapat melihat luas tanah yang telah digunakan untuk membangun dan luas tanah yang belum terbangun. Sehingga diharapkan dapat membantu pemerintah dalam mengambil langkahlangkah antisipasi dalam pengembangan pembangunan yang berkelanjutan agar tercipta ruang yang selaras, seimbang dan harmonis.

\section{Daftar Pustaka}

[1] B. Santosa, H. Sofyan, W. A. Widiyastuti, Sistem Informasi Geografis Penyebaran Penduduk Berdasarkan Tingkat Usia di Kabupaten Sleman Berbasis Web, Seminar Nasional Informatika (semnas IF 2008), ISSN 1979-2328, Mei 2008

[2] M. Kirom, Sistem Informasi Geografis Pemetaan Suara Pemilukada Berbasis Open Source di Kabupaten Jombang, Jurnal Ilmiah Edutic Vol 1. No. 1, ISSN: 2407-4489, Nopember 2014

[3] E. Irwansyah, Sistem Informasi Geografis : Prinsip Dasar dan Pengembangan Aplikasi. Digi Book, 2013

[4] E. Prahasta, Konsep-konsep Dasar Sistem Informasi Geografis, Informatika Bandung, 2002

[5] Anonim. 2011, Penyusunan Rencana Detail Tata Ruang Kota (RDTRK) Merauke, Dinas Cipta Karya Pemukiman dan Tata Ruang, Merauke 